\title{
MIKAYIL MUSHFIG, AN AZERBAIJANI POET: A VICTIM OF JEALOUSY
}

\begin{abstract}
After the collapse of the USSR in the 1990s, suitable conditions were created for the reconsideration and legal assessment of many issues. The fate of the innocent victims of Stalin's repressions in 1937 came also to the fore. It was dangerous to talk openly about such issues during the years of personality worship and the decades that followed. Although the Stalinist regime caused the partial or complete destruction of dozens of intellectual families in Azerbaijan in 1930s, it was not known where they had been buried after their execution. Of course, the discovery of those graves may provide enough information about the circumstances in which those people were killed. After executing the accused people, the local government officials tried hard to hide the results so that these crimes should remain unsolved. They knew that it could arouse suspicion, hatred and resentment against socialism. Until 2018, it was also alleged that Mikayil Mushfig, the Azerbaijani poet, who was repressed and executed by shooting in 1938 at the age of 29, was thrown into the Caspian Sea. However, 83 years later, a former officer of the People's Commissariat of Internal Affairs of the USSR (the PCIA of the USSR-HKBД) showed up and confessed that he had buried the poet near Baku after his execution in 1938. His confession has subverted much of the information that still exists in society. The article is about the assumptions which have been reported in the Azerbaijani media recently on the discovery of Mikayil Mushfig's remains. He is the youngest victim of Stalin repressions. With that in mind, Mikayil Mushfig's short life traces with a lot of rumors on his repression and execution are investigated and analyzed in this article. While searching the reasons why Mikayil Mushfig was thrown into the repression machine and shot, some other matters such as his great contribution to Azerbaijani literature during Stalin's ruling years, the plight of his family members, some intellectuals' attempts to destroy others'lives in order to save themselves, the reasons and people's attitude to the issue are also aimed to find out. It will also shed light on the activities of the terrible Stalin repressions in Azerbaijan, in which Mikayil Mushfig was killed as many other innocent people without investigating the allegations.
\end{abstract}

Key words: repressions of 1937, Mikayil Mushfig, Azerbaijani literature, Stalin's totalitarian regime, a victim of envy.

Зіяфат ГУСЕЙНОВА, orcid.org/0000-0002-9444-3325 доцент кафедри перекладу та англійської мови Бакинського інженерного університету

(Баку, Азербайджан) zhuseynova@beu.edu.az

\section{МІКАЙЛ МУШФІГ, АЗЕРБАЙДЖАНСЬКИЙ ПОЕТ: ЖЕРТВА РЕВНОЩІВ}

Після розпаду СРСР у 90-х роках були створені належні умови для перегляду та правової оцінки багатьох питань. На периий план вийшла також доля невинних жертв сталінських репресій 1937 року. Протягом багатьох років поклоніння особистості та наступних десятиліть було небезпечно відкрито обговорювати такі питання. Хоча сталінський режим спричинив часткове або повне знищення десятків інтелектуальних сімей в Азербайджані y 1930-х роках, не було відомо, де вони були поховані після страти. Звичайно, відкриття цих могил може надати достатньо інформаџії про обставини, за яких иі люди були вбиті. Після страти обвинувачених представники місиевого самоврядування всіма силами намагалися приховати результати, щуоб ці злочини залишались нерозкритими. Вони знали, що ие може викликати підозру, ненависть і образу до соиіалізму. До 2018 року також стверджувалося, щзо азербайджанський поет Мікайл Мушфіг, який був репресований $і$ страчений у результаті стрілянини у 1938 рочі у вічі 29 років, був кинутий у Каспійське море. Однак через 83 роки колишній офіцер Народного комісаріату внутрішніх справ СРСР (ПКІА СРСР-НКВД) з'явився $і$ зізнався, шьо він поховав поета під Баку після його виправдання у 1938 рочі. Його зізнання зруйнувало значну частину інформаџї, яка все ще існує в суспільстві. Стаття стосується припущень, про які нещзодавно повідомлялося в азербайджанських ЗМІ щзодо виявлення останків Мікайла Мушфіга. Він є наймолодшою жертвою сталінських репресій. 3 огляду на цее у статті розслідуються та аналізуються короткі сліди життя Микаїла Мушфіга з багатьма чутками про його репресії та страту. Під час пошуку причин, чому Мікайла Мушфіга кинули в машину репресій і розстріляли, розглянуто деякі інші питання, такі як його великий внесок в азербайджанську літературу в роки правління Сталіна, тяжке становище членів його родини, спроби деяких інтелектуалів знищити життя інших, щзоб врятувати себе, причини та ставлення людей до иьього питання. Це також проллє світло на діяльність жахливих сталінських репресій в Азербайджані, в яких Микайіл Мушфіг був убитий, як і багато інших невинних людей, без розслідування звинувачень.

Ключові слова: репресї 1937 року, Мікаӥл Мушфіг, азербайджанська література, сталінський тоталітарний режим, жертва заздрості. 
Problem statement. Mikayil Mushfig, an Azerbaijani poet, teacher and translator was born in Baku in 1908. He is an obvious example of Azerbaijani intellectuals, was shot in 1938. Because of his great contributions to Azerbaijani literature, he was considered "a king of future Azerbaijani poetry". He had published 10 books for 11 years including numerous poems and translations (Huseynoglu, 2004: 6). In addition, "after his arrest on October 13, 1937, a large part of his collection was burned by M. Mustafayev, N. Petrunin, employees of the State Security Department and Shevchenko, the chairman of the Central Executive Committee (CEC)" (Gurbansoy, 2008a: 18). Along with countless poems, translations, children's literature, Mikayil Mushfig had also dozens of ghazals. Almost all of them have disappeared or were deliberately burned. In 1932, "at the request of his friend Ali Huseynzadeh, the poet gave him a manuscript of a ghazal". This ghazal, entitled "My dear love, sweet sesame seeds", is the only ghazal survived by his friend. The manuscript was written in the Cyrillic alphabet (Gurbansoy, 2008b: 86).

Research analysis. Even today dark sides emerge at any investigation related to Mikayil Mushfig's execution by shooting. We are going to motivate following research questions in this article: What do the 1937s look like in the society and sources today? Why was he called an enemy of the people? Who was Mikayil Mushfig in reality? Is there any basis of the rumors about the discovery of the poet's grave, whose body is believed to have been thrown into the Caspian Sea? What happened to his family members? Wasn't it genocide of the intellectuals in Stalin regime in the example of the bitter fate of M. Mushfig, his family and relatives? To answer the above-mentioned research questions, the explanatory case study will be employed. The qualitative research tools for this research will enclose content analysis of the official documents, in-depth analysis of literature, numerous articles about M. Mushfig, opinion polls that are logically related to the main task of the study, as well as conversations with the older generation.

The purpose of the article is to have an objective look at the tragic life of Mikayil Mushfig, a 29-yearold young poet and his family members, who were repressed during Stalin repressions in Azerbaijan in 1938 and also to shed light on the basis of the rumors that his body had been thrown into the Caspian Sea after his execution.

\section{Presenting main material.}

The genocide of the Ismayilzadeh family members

Although the news spread that Mushfig was executed and thrown into the Caspian Sea on January 6, 1938 , no one dared to find out whether the information was true or false. As it was a frightening time, nobody could show any attempt even to open the window curtain a little and look at who was taken by an arrest car in that time. On the other hand, Mushfig's family members and all his relatives were persecuted. After Mushfig's arrest, "his elder sister Boyukkhanum told the People's Committee of Internal Affairs officers who came to arrest her that she wanted to change her clothes, went into the kitchen, poured oil on her, set her on fire and died". His younger sister, "Balajakhanum was fired and arrested in 1937 as the sister of an exposed enemy of the people, then exiled to Arkhangelsk. She lived there in a camp for six years, but she was released after being mentally ill". After "Mikail Mushfig was acquitted in May, 1956", Balajakhanum was able to return back to Azerbaijan. As the "last surviving family member, the government offered blood money" to Balajakhanum, but she refused to take it and died at her home alone in Baku, in 1970. Two sisters' spouses were also arrested and shot as Mushfig's relatives. Mushfig's elder brother, Mirza, an accountant disappeared with his family and children without a trace after his brother's shooting in 1938. Mushfig's wife, Dilbar Akhundzadeh was arrested on November 1, 1937 and tortured for two months. After a lot of severe and merciless tortures she became psychologically ill and was sent to a psychiatric hospital in 1938 . Dilbar Akhundzade was released from prison due to her mental illness in 1939. She died in 1990 in Baku, (Hasanov, 2018). Not only family members and relatives, but also Gulhuseyn Huseynoglu (1923-2013), one of the indefatigable researchers of M. Mushfig's literary heritage, was arrested during the years of personality worship, in 1945 . He fought to acquit the people who were repressed in 1937, especially Mikayil Mushfig. Therefore, he was sentenced to be shot in 1943. However, the death penalty was abolished and replaced by 25 years in prison. Fortunately, he was released after Stalin's death in 1955 (Abdullayev, 2019). Apparently, after Mikayil Mushfig's execution, there was not any family member left to inquire about the location of his grave. However, the poet's body was supposed to be thrown into the Caspian Sea until 1994.

In spite of the presumptions, a former supervisor named Ali Alistan, who claimed to have the poet, refuted these claims. Researchers Hasanov and Novruzoglu tried to identify the man who confessed to burying him. It turned out that "an Azerbaijani sergeant named Ali Mardan Alistan, who knew both Russian and Azerbaijani languages, had been really chosen to monitor M. Mushfig's cell" and translate the investigation materials into Russian on November 26, 1937. Ali Alistan claimed that after the death 
sentence on the night of 5 to 6 January, he had carried "the body of the convicted № 1109 to the Bayil cemetery" and buried him in one of the unmarked graves, wrote his own name "Ali" on the gravestone with "the intention that the grave would be identified in future". The Inspector Sinman, who was interrogating the poet, also had mentioned the name of the person "in a reference given to the investigation group of the General Intelligence Agency". The reference shows that "the appointment of sergeant Ali Mardan Alistan to the cell of prisoner N.1109 had changed significantly" (Hasanov, Novruzoglu, 2017). After more than eight decades, if we believe Ali Mardan Alistan's confession in 1994, Mikayil Mushfig was buried in a secret cemetery of the PCIA of the USSR in Puta settlement of Garadagh district in Baku, Azerbaijan, where other victims of the repressions are also believed to be buried. The government officials with the members of the media attended the cemetery, and "the remains alleged to belong to the poet were exhumed from the secret cemetery of the PCIA". Whether the grave belongs to our great poet will only "be determined after DNA testing". However, since no relatives of Mushfig's mother's side are alive, it will probably be necessary to open his younger sister Balajakhanum's grave, "to prove that the specimens really belong to Mikayil Mushfig" (Expertise of the remains, 2018).

The Picture of Repression in Azerbaijan and its Influence on Mikayil Mushfig

It is important to draw attention to what was happening in Azerbaijan when M. Mushfig shone as a poet. "Document No. 57788 on the operational work in the Turkish-Tatar nationalist organizations of the Soviet Union" states that the PCIA carried out "mass repressions in the territory of the Soviet Union, including the Azerbaijan SSR in 1937 and 1938 years. "With the appointment of Nikolai Yezhov as the General Commissioner of this organization" (from September 26, 1936 to November 25, 1938), this work was more accelerated (Directive of the PCIA, 1937). There was almost no family in Azerbaijan that had not been penetrated and suffered from this person. Nikolai Yezhov was considered to be a tyrant who had "no compassion in his heart for people. He also demanded his subordinates to show special cruelty and mercilessness to the intelligentsia, and ordered the use of unimaginable torture on those under investigation". N. Yezhov, General Commissioner signed another order No. 00447 on the operation to repress former strikers, criminals and other anti-Soviet elements" on July 30, 1937. After this directive, "the traces of anti-sovietism began to be sought in all organizations, departments, second- ary schools, and scientific institutions that hindered communism, exposing the enemies of the people" (The operation on repression, 1937).

According to this order, it was necessary to destroy the political enemies immediately and neutralize those who wanted to change the political regime. N. Yezhov had planned in advance for each republic: For example, "1 500 people from the Azerbaijan Soviet Republic should be punished in the first category, 3750 in the second category", it would be 5250 people totally. "Detainees in the first category would be shot, and those in the second category would be sentenced to 8-10 years in prison" (Sirajoglu, 2019). Therefore, "N. Yezhov and A. Vyshinsky, a prosecutor of the USSR, signed a verdict deciding the fate of 21,222 prisoners" in Azerbaijan with the support of the local informants in Stalinist repressions of 1937-1938. The local informants were considered "the minions of Stalin's regime" and they were busy with "writing slander and calumny about the suspected intellectuals". In order to escape the repressions, those poets presented themselves as the fans of socialism, and in this way, "they annihilated their rival intellectuals by portraying them as enemies of socialism". The informants sent "69,000 letters from Azerbaijan to the 6th Section of the General Intelligence Department in 1937, which was controlling the state's science, education, literature, art, and health systems. About $85 \%$ of the letters were sent back to Azerbaijan from Moscow for investigation and measure". In Azerbaijan, however, Russian-speaking "employees of the State Security Department did not investigate these letters fairly and did not want to reveal the truth" (Hasanov, 2018).

R. Sirajoglu, a researcher investigating the activities of the PCIA in Azerbaijan, writes that "there were people in all organizations, departments, enterprises and workplaces who willingly provided the PCIA with information obviously". They immediately wrote "exposing" information about the arrested intellectuals insulting them with the most absurd expressions. It is probably why "the Azerbaijani literature suffered most from the repressions in the Caucasus in 1937 and 1938 years" (Sirajoglu, 2018a). Taking advantage of the turmoil of the time, some betrayers also targeted Mikayil Mushfig. They were envious of his talent and did not want to see him as a pearl of Azerbaijani poetry in the future. That's why they did their best to put him into one of those two categories to be shot or arrested. Yezhov's policy of "cleansing the ground" provided an opportunity for the traitors to carry out their intentions. To achieve this purpose, '29 out of 60 members of the Writers' Union of soviet Azerbaijan, including Mammad Rahim, Abdullah Akbar, Mikayil Rzaguluzade, Seyfullah Shamilov, 
Asad Ayyubi, Mirmehdi Seyidzadeh, Mammadkazim Alakbarli wrote the denunciations about Mikayil Mushfig. The group of denouncers knew perfectly well that the written denunciations against him would sooner or later put this talented poet to death" (Who calumniates, 2017).

The Writers' Disease of Envy and Their Attack to the 29 Years Old Poet

It is no coincidence that the subtitle is called "The Writers' Disease of Envy". I have read Bonita Fredman's article "Envy is a Disease of Writers" nowadays. Until now, I haven't known that the poets and writers are more jealous than other people. The author especially emphasizes that "for most writers, envy is a professional hazard. It wallows in his head, distracting from his own work, in the most dangerous form, even able to wake the patient from sleep so that he ponders another's triumph" (Friedman, 1989). Similarly, some of the Azerbaijan Soviet Writers' envious hostility against M. Mushfig increased so much in 1937, even they did not care deliberately that they had endangered the poet's life. Indeed, a lot of envious poets could not accept Mushfig's success. Those poets, who were thinking only of the material side of life and were in search of fame, were afraid that Mushfig would overtake them in the field of poetry. For this purpose, his poems were dressed differently, translated into Russian in a different context on purpose. He was presented as a fearsome revolutionary. For example, Mushfig wrote these lines in his poem "Winds" as "take me too, let me fly to the mountains, let me open whatever is in my heart to the mountains!". However, this verse was intentionally interpreted like "Mushfig wants to run to the mountains and expresses his secret thoughts there. If he has no hidden evil intentions, why does he want to climb the mountains?". Another example, it was claimed that M. Mushfig had a coded message in the phrase "My lover is in a green dress" in his poem "Like". They tried to convey that "why Mushfig depicts his lover in a green dress? Isn't it known that this color is a symbol of Islam? Is there no other color?". One else, they also found the counter-revolutionary call in Mushfig's lyrical poem "Clouds", which skillfully describes nature. The traitors claimed that "the poet allegedly calls the people to an armed uprising" in this verse "I am in a better mood, and I'm ready to flash like lightning" (Sirajoglu, 2018b).

A lot of detestable articles were regularly published in the "Literature", "Young Worker", "New Way" newspapers, "Attack", and "Revolution and Culture" magazines against the poet in the 1930s. A bespoke article entitled "The Remains of the Enemy in the Literature must be exposed to the End" was published in № 141 of the "Communist" newspaper on June 20, 1937. It was written by a poet, Abdullah Farooq, that Mikayil Mushfig "contradicted the socialist system and continued his suspicious deeds openly and secretly. He must be eliminated as a Musavatist and Trotskyist counter-revolutionary because he has a perverse hatred and enmity against our great socialist system" (Mikayil Mushfig., 2013). During the period of repression, people suspected of spreading anti-Stalin views in Azerbaijan were called "Trotskyists". The author of the article also called the poet "Trosky's supporter" without any reason. In short, the author was able to draw the PCIA authorities' attention to Mikayil Mushfig. Another article against M. Mushfig was published in the newspaper "Literature", the issue № 25 (110) on 9 June, 1937. The article named "Let's clean our rows" written by Jafar Khandan, called Mikayil Mushfig as "an enemy of the people and socialism" (Gurbansoy, 2008c: 91).

Despite all these misleading information, M. Mushfig was loved by the people and called a Soviet poet. He applauded the victory of socialism and emphasized "freedom" as "a deep spirit of the world", "spirit of an art and poetry". He believed that Socialism would bring happiness to his people and homeland. Even he dedicated a poem to Stalin in 1936. However, the traitors, who "undertook to criticize Mushfig" and insured themselves against the forthcoming repressions, "did not accept this poem unequivocally". At one of the following plenums in 1937, Mikail Rzaguluzadeh, a member of the Writers' Union, attacked to M. Mushfig personally claiming that there were counter-revolutionary challenges in his poem "Stalin". He "passed through the part of the poem which had been dedicated to Stalin". Like this slingshot, he even accused Mushfig of "not knowing Russian, reading old books and using" them. He dressed out every positive thought of the poet in different attire. Mammad Rahim, another member of the Writers' Union, published an article in the "Literature" newspaper entitled "Counter-revolutionary, smuggler, thief" criticizing Mikayil Mushfig sharply on July 1, 1937. He tries to prove that his works "are apparently soviet, but the whole internal structure is full of brutal counter-revolutionary spirit". His booklet "Winds" is full of "all sorts of flamboyant, anarchist, nasty and black anti-Soviet counter-revolutionary ideas" (Kanan, 2011a: 98).

\section{Mikail Mushfig's Unjust Arrest and Hasty Exe-} cution

Dozens of such articles had been published about M. Mushfig and "legal basis" had already been laid for his arrest. To speed up the process, captain Thinman, a Security of the PCIA in Azerbaijan, wrote in a 
statement on May 27, 1937 that "Mikayil Mushfig is currently in contact with the Musavat youth organization, does not hesitate to slander the party and the government". He arouses discontent among the people with such provocative words as "Azerbaijan has no freedom; it lives in a Russian colony". Moreover, the "voluntary" explanations of the arrested defendants were also taken into account. Consequently, "warrant No. 508 was issued in the name of Mikayil Mushfig according to the certificate prepared by the investigator" on June 3 and he was arrested at his home on June 4, 1937. During seven months in prison, he was being subjected to unprecedented torture asking him about his membership and position as a nationalist in Musavat organization. Then, Sumbatov, a chief of the PCIA in Azerbaijan and Rozovsky, General Assistant of USSR Prosecutor, signed the indictment. They deliberately wrote that Ismayilzadeh Mikayil Mushfig "admits that he has adhered to almost all the decisions of the counter-revolutionary organization" (Kanan, 2011b: 135).

It is said that until the last day, Mushfig did not believe he would be killed, but he believed to be released. He was absolutely sure that "his arrest was the effort of people who were jealous of him. None of the arrested intellectuals was seriously guilty in that time. One spoke a little harshly, another wrote carelessly, and so on. However, humanist socialism could forgive them" (Gurbansoy, 2008d: 71). Could a society in which the betrayers play a main role be humanist? Not only that "humanist society", but those traitors also issued a fatwa on Mushfig's death in 1938.

Finally, "Ismayilzade Mikayil Mushfig was found guilty under the Articles 64, 70, 73 of the Criminal Code of the Azerbaijan SSR" on the basis of false testimony. After that, "the trial of the Mobile Military Board of the Supreme Court of the USSR, which began at 11:20 on January 5, 1938, ended at 11:40 with the verdict in the execution of Ismayilzade Mikayil Mushfig. The sentence was carried out on the night of January 6, on the island of Nargin near Baku" (Kanan, 2017). Since then the rumors about the poet's execution have not ended. It was rumored that the first bullet even was fired by Mirjafar Bagirov himself, First Secretary of the Central Committee of Azerbaijan Communist Party. According to researcher R. Sirajoglu, "this idea does not seem convincing". He explained that "the political leader of the republic could not have had the opportunity to find out who were arrested by the PCIA". Moreover, M. Bagirov didn't seem to be hostile to Mushfig. "In 1936, the state commission chaired by M. Bagirov awarded his poem "Morning" as one of the "Seven best literary works" at the poetry contest dedicated to the 15th anniversary of the establishment of Soviet power in Azerbaijan". Furthermore, "Mikail Mushfig was a laureate of the Republican Komsomol award". If M. Bagirov did not have special sympathy for him, it is unlikely that anyone "would have dared to consider Mushfig worthy of this award". In addition, "Mikayil Mushfig was the director of a very serious publishing house such as Azerneshir, where all serious political and social works were published. If M. Bagirov did not trust Mushfig, who would nominate him for that position?". It should be noted that "the texts of M. Bagirov's speeches were prepared by the Secretariat for Ideological Affairs of the Central Committee". It is clear that "the written information was required from the heads of various fields during the preparation of those texts". Then the leaders of the "local relevant agencies provided the Central Committee with required information". It is clear that the information about "the activities of the writers and poets were prepared by the chairman of the Azerbaijan Soviet Writers' Union" exactly in that period (Sirajoglu, 2018c). The author of the article tries to prove with a lot of evidences that Mirjafar Bagirov was not directly related with this murder. However, it can be a question, how Mirjafar Bagirov, General Secretary of Azerbaijan Soviet Republic, who did not forgive the slightest criticism or the most ordinary mistakes of his employees, kept every point of the republic under full power and control, became unaware of Mushfig's death?!

\section{Attitude to Mikayil Mushfig's Shooting Death in Modern Society}

83 years have passed since the poet's execution. We decided to conduct a survey to know the people's opinion about the poet's death. Although his name was not mentioned in any activities of the political parties or organizations, he was dragged to death deliberately. We asked 500 people including 200 students, 200 young people over the age of 35 , and 100 people between the ages of 65 and 75 to participate in the survey. We have grouped the results by summarizing the individual and collective inquiries.

It can be seen from the table, the survey was held among different age groups. $86.5 \%$ of the students (173), $90.5 \%$ of the young people (181), $90 \%$ of the adults (90) think that not all the victims of the repressions in 1937 were counter-revolutionaries. Almost $88.8 \%$ of the participants support it totally. Due to the confusion and inaccuracy of information about Mushfig, $8.2 \%$ of the survey members do not know the answer exactly. The older generation, on the other hand, unequivocally think that most of them are also innocent like M. Mushfig. 78.2\% of respondents' answers stand for M. Mushfig not to do any 
People's views on the execution of Mikail Mushfig

\begin{tabular}{|l|l|l|l|}
\hline \multicolumn{1}{|c|}{ Questions of the survey } & \multicolumn{1}{|c|}{ Students (200 people) } & $\begin{array}{l}\text { Young people aged 35-50 } \\
\text { (200 people) }\end{array}$ & $\begin{array}{c}\text { 65-75 years old adults } \\
\text { (100 people) }\end{array}$ \\
\hline $\begin{array}{l}\text { 1. Were all the Azerbaijani } \\
\text { intellectuals shot during the } \\
\text { repressions of the 1930s really } \\
\text { counter revolutionaries? }\end{array}$ & $\begin{array}{l}8-\text { yes; } \\
173-\text { not all; } \\
19-\text { did not know }\end{array}$ & $\begin{array}{l}7-\text { yes; } \\
181-\text { not all; } \\
12-\text { did not know }\end{array}$ & $\begin{array}{l}0-\text { yes; } \\
90-\text { not all; } \\
10-\text { did not know }\end{array}$ \\
\hline $\begin{array}{l}\text { 2. Why was Mikail Mushfig } \\
\text { shot? Out of jealousy or } \\
\text { political views? }\end{array}$ & $\begin{array}{l}168-\text { out of envy; } \\
22-\text { for his political } \\
\text { views; } \\
10-\text { refused to answer }\end{array}$ & $\begin{array}{l}177-\text { out of envy; } \\
8-\text { for his political views; } \\
15-\text { refused to answer }\end{array}$ & $\begin{array}{l}46-\text { out of envy; } \\
3-\text { for his political views; } \\
51-\text { refused to answer }\end{array}$ \\
\hline $\begin{array}{l}\text { 3. Do you know the direct } \\
\text { culprit in Mikail Mushfig's } \\
\text { execution? }\end{array}$ & $\begin{array}{l}170-\text { Mushfig's own } \\
\text { colleagues; } \\
5-\text { the leadership of } \\
\text { Azerbaijan at that time; } \\
25-\text { all above }\end{array}$ & $\begin{array}{l}168-\text { Mushfig's own } \\
\text { colleagues; } \\
12-\text { the leadership of } \\
\text { Azerbaijan at that time; } \\
\text { 20-all above }\end{array}$ & $\begin{array}{l}60-\text { Mushfig's own } \\
\text { colleagues; } \\
19-\text { the leadership of } \\
\text { Azerbaijan at that time; } \\
21-\text { all above }\end{array}$ \\
\hline
\end{tabular}

act against socialism. It is firmly believed that those who were jealous of his success in poetry caused him to be executed. The majority almost think that he became a victim of the jealousy by his comrades, $6.6 \%$ think the poet was killed because of his political views. According to $13.2 \%$ of respondents reply, all the sides are guilty logically in the poet's death. This is absolutely true. Even though the answers to the question of who killed Mushfig are relatively close: $79.6 \%$ of the answers note that he was dragged to death by their colleagues. It is an undeniable fact that Stalin repressions were exactly carried out by the help of the local supporters' cooperation in Azerbaijan. It is also clear from the poll that the men who are the direct culpit for Mushfig's murder was the then members of the Azerbaijan Soviet Writers' Union in 1930s. Based on the results obtained from the table, we tried to look at the general picture of 1937 and the events surrounding the poet would soon have sacrificed him to repression.

Conclusions. While searching we used a lot of archival documents such as Stalin's repressions in Azerbaijan, all the information based on the related investigations and the beginning of the DNA analysis of the poet's remains. It became clear from the survey and research that the intellectuals who mainly criticized the government, refused to praise the regime, and called on people to fight against socialism were not the only ones who were repressed in 1930s. In fact, hundreds of innocent people have been the victims of slander and libel by local denunciators. We also examined the poet's contributions to Azerbaijani literature and the content of the collection of poems which were preserved. It turned out that Mikayil Mushfig's poems were about the motherland, people, nature, love and affection. He did not write a poem for political reasons, nor did he call the people to revolt against socialism. In general, his poetic talent, creating a new style and a unique world of poetry in a short period caused him to get rapid popularity at a young age. Therefore, he became the target of jealousy. Our assumptions that Mushfig was dragged to his death by his intellectual friends were confirmed by surveys and the information in the articles alternatively. We also considered that when Stalin repressions attacked the nations like an irresistible flood, the then Azerbaijani poets did not support Mushfig on purpose. On the contrary, they acted with the insidious intention that if Mushfig left, there would no longer be a rival in poetry in front of them. With this intention he was dragged to his death. Although the injustice against Mushfig stemmed from the policy pursued by the Stalinist regime, the crime was directly highlighted as a deed of local patrons. Due to precise information restrictions and biased attitudes by those poets themselves and later by their children, the Azerbaijani people didn't get true information. In order to distract attention from the basic cause on purpose in Soviet period, they have sought only political motives for the poet's execution. The deeds of the Azerbaijan Soviet Writers' Union in 1937 against a young poet sets the stage for a long-lasting mistrust of them that still persists. It is also clarified that they have caused a complete destruction of an intellectual family. Most importantly, the traitors caused a loss that Azerbaijani literature will look for the decades to come back. Besides it, the killer's confessing the past is not daring. After 83 years, it can be a step to be free from remorse in the last days of his life partially and also a hope to sleep in the grave peacefully. The examination of the poet's remains, which began in 2018 , is going on. 


\section{BIBLIOGRAPHY}

1. Abdullayev T. Atam rəhmətə gedib, Müşfiqi də mənimsəyiblər. Retrieved June 6, 2020. 2019/ URL: https://axar.az/ news/musahibe//478602.html.

2. Azərbaycan poeziyasının Mikayıl Müşfiq zirvəsi. Metodik vəsait, tərtibçi L. Ohmədova; elmi red. K. M. Tahirov; red. G. Səfərəliyeva. Bakı: Azərbaycan Milli Kitabxanası, 2018. 108 s.

3. Friedman B. Envy, The Writer's Disease. Retrieved August 4, 2020. 1989. URL: https://www.nytimes.com/11/26/ books/envy-the-writer-s-disease.html.

4. Həsənov H. Azərbaycan Yazıçılar Birliyinin 26 üzvü Mikayıl Müşfiqə qarşı ifadə verdi. Retrieved July 7, 2020.2018. URL: http://www.anl.az/uc noqta//616732.html.

5. Həsənov H., Novruzoğlu R. Mikayıl Müşfiq: Mən gəncəm, bilirəm, istiqbalım var, Hələ bədr olmamış bir hilalım var! Retrieved Mart 5, 2020. 2018. URL: http://xalqqazeti.com/ru/news/8423.

6. Musfiqin qaliqlarinin-ekspertizasi-baslayir. Retrieved October 24, 2020. 2018. URL: http://www.anl.az/down/meqale/ uc_noqta/616732.html.

7. Mikayil-Musfiq-Kontrrevolusioner-Kontrabantci-Ogru. Retrieved April 5, 2020. 2013. URL: https://fatimekerimli. wordpress.com $/ 2013 / \mathrm{m}$-rahim.

8. Hüseynoğlu G. Mikayıl Müşfiq. Seçilmiş əsərləri. Bakı : Şərq-Qərb, 2004, 351 p.

9. Kənan A. XX əsrdə repressiyaya məruz qalanlar. Bak1 : Azərnəşr, 2011. 296 s.

10. Kənan A. Dünyadan əl çəkə bilməyən şairin güllələndiyi gün. Retrieved October 10, 2020. 2017. URL: http:// femida.az/az/news/4539323.

11. Qurbansoy, F. Göylərin lacivərd ətəklərində: sənədli povest-kollaj / red. V. Qaradağl1; Azərb. Resp. Mədəniyyət və Turizm Nazirliyi. Bakı : Qərənfil MMC, 2008. 123 s.

12. Mikay1l Müşfiqin üzünə duranlar-Onlar kimlərdir? 2017. Retrieved September 5, 2020. URL: http://www.enter.news/ az/news/interesting/55605.

13. Novruzoğlu R., Həsənov H. Müşfiqin məzarı ilə bağlı yeni versiya. Retrieved May 9, 2020. 2018. URL: http:// faktxeber.com/ h522008.html.

14. Siracoğlu R. Özü-özünü yandıran atəş - Mircəfər Bağırov Mikayıl Müşfiqə nələri etibar etmişdi. Retrieved August 30, 2020. 2018. URL: http://www.oxumeni.az/news/culture/79971.html.

15. Siracoğlu R. Mikayıl Müşfiq ən çox nədən qorxurdu və niyə öldürüldü? Retrieved August19, 2020. URL: https:// www.bakupost.az/mikayil-musfiq.

16. Об оперативной работе по антисоветским тюрко-татарским националистическим организациям : Директива НКВД СССР от 8 июля 1937 г. № 57788. Retrieved July 18, 2020. URL: http://www.oxumeni.az/news/culture/79971.html.

17. Об операции по репрессированию бывших кулаков, уголовников и др. антисоветских элементов. Retrieved November 18, 2020. URL: http://eao.memo27reg.org/politiceskie-repressii-v-sssr-1937-1938-godov-priciny-masstabyposledstvia.

\section{REFERENCES}

1. Abdullayev, T. (2019). Atam rəhmətə gedib, Müşfiqi də mənimsəyiblər. [My father died and Mushfig was adopted]. Retrieved June 6, 2020 from https://axar.az/news/musahibe/478602.html. [in Azerbaijani].

2. Azərbaycan poeziyasının Mikayıl Müşfiq zirvəsi. Metodik vəsait, tərtibçi L. Ohmədova; elmi red. K. M. Tahirov; red. G. Səfərəliyeva. [Mikayil Mushfig, summit of Azerbaijani poetry. Methodical aids; scientific ed. K. M. Tahirov; ed. G. Safaraliyeva. Baku: Azerbaijan National Library]. Baku: Azerbaijan National Library, 2018. 108 p. [in Azerbaijani].

3. Friedman, B. (1989). Envy, The Writer's Disease. Retrieved August 4, 2020 from https://www.nytimes.com/11/26/ books/envy-the-writer-s-disease.html. [in English].

4. Həsənov, H. (2018). Azərbaycan Yazıçılar Birliyinin 26 üzvü Mikayıl Müşfiqə qarşı ifadə verdi. [26 members of the Writers' Union of Azerbaijan testified against Mikayil Mushfig]. Retrieved July 7, 2020 from http://www.anl.az/uc noqta//616732.html. [in Azerbaijani].

5. Həsənov, H., Novruzoğlu, R. (2018). Mikayıl Müşfiq: Mən gəncəm, bilirəm, istiqbalım var, Hələ bədr olmamış bir hilalım var! [I am young, I know I have a future, I have a crescent that has not yet formed!]. Retrieved Mart 5, 2020 from http://xalqqazeti.com/ru/news/8423 [in Azerbaijani].

6. Musfiqin qaliqlarinin-ekspertizasi-baslayir. (2018). [Expertise of the remains of Musfiq begins]. Retrieved October 24, 2020 from http://www.anl.az/down/meqale/uc_noqta/616732.html. [in Azerbaijani].

7. Mikayil-Musfiq-Kontrrevolusioner-Kontrabantci-Ogru. (2013). [Mikayil Musfiq-Counterrevolutionary-SmugglerThief]. Retrieved April 5, 2020 from https://fatimekerimli.wordpress.com/2013/m-rahim. [in Azerbaijani].

8. Hüseynoğlu, G. Mikayıl Müşfiq. Seçilmiş əsərləri. [Mikayil Mushfig. Selected works]. Baku, "East-West”. 2004. 351 p. [in Azerbaijani].

9. Kənan, A. XX əsrdə repressiyaya məruz qalanlar. [The Victims of the Repressions in the twentieth century]. Baku: Azerneshr, 2011. 296 p. [in Azerbaijani].

10. Kənan, A. (2017). Dünyadan əl çəkə bilməyən şairin güllələndiyi gün. [That day the poet, who could not give up the world, was shot]. Retrieved October 10, 2020 from http://femida.az/az/news/4539323. [in Azerbaijani].

11. Qurbansoy, F. Göylərin lacivərd ətəklərində: sənədli povest-kollaj / F. H. Qurbansoy; red. V. Qaradağli; Azərb. Resp. Mədəniyyət və Turizm Nazirliyi. [At the foot of the dark blue skies: documentary story-collage / F. Gurbansoy; ed. V. Garadagli; Ministry of Culture and Tourism]. Baku: Garanfil LLC. 2008. 123 p. [in Azerbaijani].

12. Mikayıl Müşfiqin üzünə duranlar - Onlar kimlərdir? (2017). [Those who slander Mikayil Mushfig - Who are they?]. Retrieved September 5, 2020 from http://www.enter.news/az/news/interesting/55605. [in Azerbaijani]. 
13. Novruzoğlu, R., Həsənov, H. (2018). Müşfiqin məzarı ilə bağlı yeni versiya. [New version about Mushfig’s grave]. Retrieved May 9, 2020 from http://faktxeber.com/_h522008.html. [in Azerbaijani].

14. Siracoğlu, R (2018). Özü-özünü yandıran ătəş - Mircəfər Bağırov Mikayıl Müşfiqə nələri etibar etmişdi. [Self-immolation - What did Mirjafar Bagirov entrust to Mikayil Mushfig?]. Retrieved August 30, 2020 from http://www.oxumeni.az/ news/culture/79971.html. [in Azerbaijani].

15. Siracoğlu, R. Mikayıl Müşfiq ən çox nədən qorxurdu və niyə öldürüldü? [What was Mikayil Mushfig most afraid of and why was he killed?]. Retrieved August 19, 2020 from https://www.bakupost.az/mikayil-musfiq [in Azerbaijani].

16. Direktiva NKVD SSSR № 57788 ob operativnoy rabote po antisovetskim tyurko-tatarskim natsionalisticheskim organizatsiyam, ot 8 iyulya 1937 g. [Directive of the PCIA of the USSR № 57788 on operational work on anti- Soviet Turkish-Tatar nationalist organizations, July 8, 1937]. Retrieved July 18, 2020 from http://www.oxu meni.az/news/culture/79971. html. [in Russian].

17. Ob operatsii po repressirovaniyu byivshih kulakov, ugolovnikov $\mathrm{i}$ dr. antisovetskih elementov. [The operation on repression of former fists, criminals and other anti-Soviet elements]. Retrieved November 18, 2020 from http://eao.memo27reg.org/politiceskie-repressii-v-sssr-1937-1938-godov-priciny-masstaby-posledstvia. [in Russian]. 